CURRENT RESEARCH JOURNAL OF PHILOLOGICAL SCIENCES 2(12):

130-133, December 2021

DOI: https://doi.org/10.37547/philological-crjps-02-12-26

ISSN 2767-3758

(C)2021 Master Journals

crossref do) :810 Google

Accepted1 $7^{\text {th }}$ December, 2021 \& Published 22 ${ }^{\text {th }}$ December, 2021

\title{
ORGANIZATION AND IMPLEMENTATION OF THE ORGANIZATION OF PEDAGOGICAL EXPERIMENTS
}

\section{Madina B. Ganihanova}

Lecturer Department Of Foreign Languages Tashkent State Technical University Named After Islam Karimov, Uzbekistan

\section{ABSTRACT}

As noted above, the modern educational system functions in special conditions, the specifics of which are determined by the global process of informatization of education, therefore, it became necessary to possess special means that help to navigate there. These tools are multimedia tools (MMC).

KEYWORDS: - Media education, pedagogical level, methodological level, Projects Method, Case Study Technology, Technology "Debate, perception.

\section{INTRODUCTION}

We are focused on the formative experimental phase of our research. The purpose of the formative experiment is to create and test a media education model based on technical data for the process of training future specialists. For the development of critical thinking in the perception of secondary information, it is necessary to reveal the possibilities of media education technologies in enhancing the cognitive activity of students. To achieve this goal, the following tasks have been identified: 
CURRENT RESEARCH JOURNAL OF PHILOLOGICAL SCIENCES 2(12):

130-133, December 2021

DOI: https://doi.org/10.37547/philological-crjps-02-12-26

ISSN 2767-3758

(C)2021 Master Journals

Crossref dof 81 Google

Accepted1 $7^{\text {th }}$ December, 2021 \& Published 22 ${ }^{\text {th }}$ December, 2021

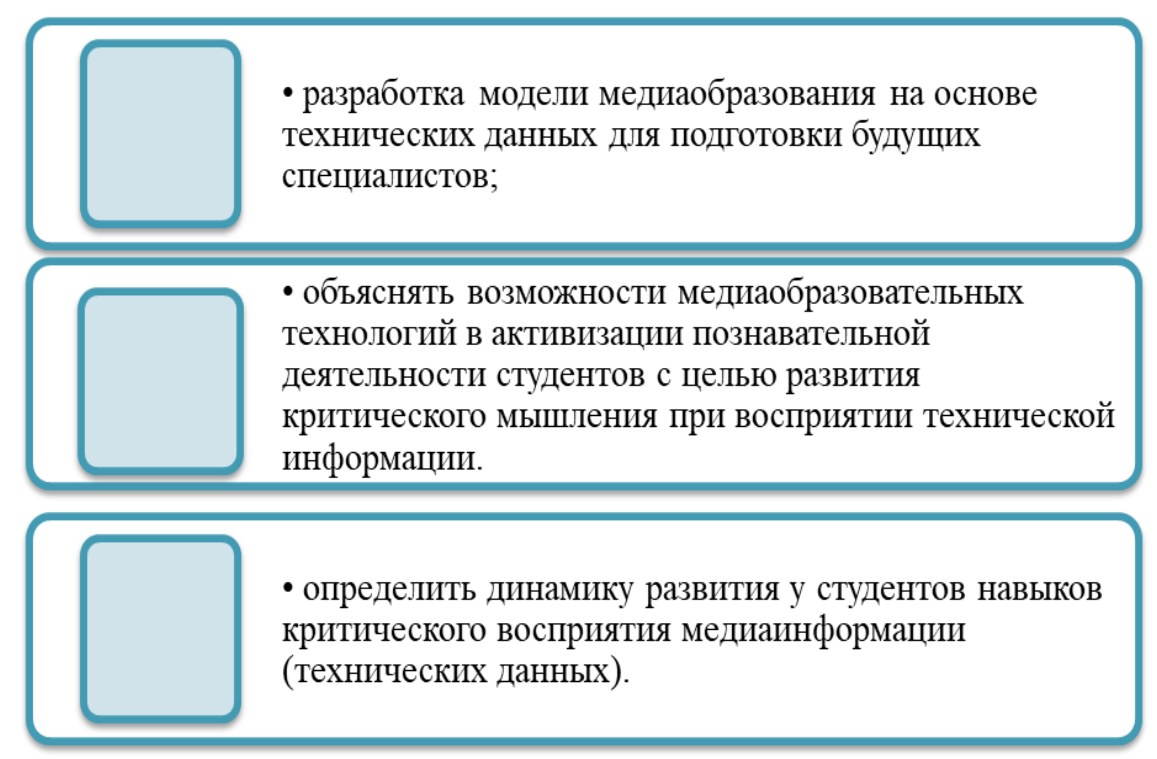

\section{Materials AND METHOdS}

In the study, when developing a model of media education for students based on technical data, we relied on the main ideas that determine the development of modern education and are reflected as guiding principles in the professional and personal development of students:

- personal approach. This allows us to consider a person as a subject of life. In this process, his activities are aimed at changing the real pedagogical reality and types of personal activities. At the same time, creativity is the highest indicator of the results of human activity and the ability to realize one's potential; in the context of personality-oriented production activity, the condition for the realization of professional and personal potential is understood;

- systems approach. Allows you to determine the variety of descriptions of interactions (objectobject, subject-subject, content-technological, content-target, content-regulating) in the learning process; a systematic approach manifests itself as a scientific principle of access to different areas of knowledge and the discovery of their new essence; The systematic approach ensures stability, balance, stability, integrity in the learning space, on the one hand, and on the other hand, the subject and objects of the controlled system require certain interactions in horizontal-vertical relations. These relationships create a certain matrix of the educational process. Includes a model of educational and methodological support for students and teachers and the organization of independent work;

- a synergistic approach, understood as a set of components that differ in meaningful categories, laws of space and time, system-forming factors, qualitative and quantitative characteristics, rhythm and ratio of all components; a synergistic approach reveals ways of interpreting pedagogical information and analyzing the legitimacy of the pedagogical process, which allows us to develop new ways of obtaining high-quality information;

- a synergistic approach is a necessary condition for the development of personality and the construction of an integrated educational process in 
CURRENT RESEARCH JOURNAL OF PHILOLOGICAL SCIENCES 2(12):

130-133, December 2021

DOI: https://doi.org/10.37547/philological-crjps-02-12-26

ISSN 2767-3758

(C)2021 Master Journals

Crossref $d$

gil Google

Accepted17 th December, 2021 \& Published 22 ${ }^{\text {th }}$ December, 2021

pedagogical disciplines; The synergistic approach assumes a periodic change in behavior in social groups, which includes active personality development and self-organization, selfimprovement, performance, types of behavior, worldview and other conditions;

- Demonstrates creativity based on a cultural approach as a result of self-awareness and content of the human person; cultural values - areas of production that determine the development of personality and human behavior; the process of activity is considered as a method of selftransformation and self-development in independent activity.

As part of our study of media texts, the general concepts of students were based on the organization of a special 60-hour course "Technical English Media Education", which included: 18 hours of lectures and 18 hours of seminars and 26 hours of independent work. The program of the special course (Appendix 1) includes the study of the following topics:

1. Information environment of society.

2. Media culture. media perception process, psychology of media concept.

3. Media education: topic, goals, media, theory of media education.

4. The main historical stages of the development of the media in Uzbekistan and abroad.

5. Technical data: concept, objectives, goals and types.

6. Psychotechnology of technical data.

7. Psychological manipulation of technical data.

8. Information and psychological security of a person.

The methodology of the special course involves the implementation of a variety of creative tasks that perform specific functions. The training function includes the acquisition of knowledge about theories of media activity, models for the analysis and analysis of media texts, technologies for transferring technical data and the possibilities of confronting a person using manipulative media methods. The developmental function is based on the development of a person's motivational (compensatory, therapeutic, recreational, etc.), volitional and other qualities and attributes, the experience of creative communication with the audience. In the process of teaching students media materials based on technical data, various methods were used: descriptive - publishing content, recording events, etc.; analytical and analytical composition and language of the media, author's positions, orientation to a specific audience, etc. personal - a description of relationships, experiences, associations arising from the text of a particular mass media

Receptions are central to the learning activities of students and have a decisive effect on it. Thanks to a skillful combination of interconnected techniques, the teacher manages to increase the effectiveness of the educational process, to show his methodological skills. Working with isolated lexical units on the board, analyzing the structure of the written sentences, controlling loud pronunciation of words, phrases, naming objects in pictures - these are all examples of tricks that help to solve separately posed problems. But it should be noted that the weak level of formation of techniques is one of the reasons for the difficulties students encounter in learning, especially when doing homework on their own.

In contrast to the technique, the method should be considered as a second and higher power generalization stage.

\section{Conclusion}

In addition, communication includes the ability to receive information via the Internet, as well as to 
CURRENT RESEARCH JOURNAL OF PHILOLOGICAL SCIENCES 2(12):

130-133, December 2021

DOI: https://doi.org/10.37547/philological-crjps-02-12-26

ISSN 2767-3758

(C)2021 Master Journals

Crossref do

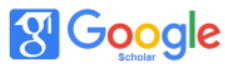

Accepted1 $7^{\text {th }}$ December, 2021 \& Published 22 ${ }^{\text {th }}$ December, 2021

provide information for others to use, so students on the Internet can be both consumers and producers of information at the same time.

The tradition of the classification indicates that at each practical lesson it is possible to find tasks to achieve the set goals.

The teacher's introductory remarks at the beginning of each lesson allowed the students to clearly articulate goals and a process for completing the assignments. In further activities, the teacher acted as a consultant.

In addition, there is a close relationship between thematic interest and knowledge acquisition. A well-organized educational work using the media can be unsuccessful if students show little interest in the proposed topics. The use of media most often brings with it some novelty effect, which can lead to a motivated and interesting presentation (consideration) of the material, but this interest decreases again after a certain time.

The differences between inexperienced users and so-called experts are also important. As modern children and adolescents grow up in a world of strong media influence, the forms of mastering new media technologies should look different than in the case of adults.

\section{REFERENCES}

1. Rabinovich F.M., Sakharova T.V. Intensive teaching methods and high school. - Foreign languages at school, 1991, No. 1.

2. Merkulova I.I. The system of problem tasks in teaching reading // IYASH, 1991, No. 6.

3. Milrud R.P. Discussion of the problem in the lesson of a foreign language // IYASH, 1986, No. 4.

4. Mirolyubov A.A. Palmer's method // IYASH, 1995, No. 1.

5. Mirolyubov A.A. Audio-lingual method // IYASH, 1995, No. 4.

6. Rabinovich F.M., Sakharova T.V. Intensive teaching methods and high school. - Foreign languages at school, 1991, No. 1.

7. Denisova L.G. The place of intensive methodology in the system of teaching a foreign language in high school. - Foreign languages at school, 1995, No. 4.

8. Dianova E.M., Kostina L.G. Role-playing game in teaching a foreign language (review of foreign methodological literature) // IYASH, 1988, No. 3.

9. Theory of teaching foreign languages: Linguodidactics and methodology: textbook / ND Galskova, NI Gez.-6th ed., Sr.- M.: Academy, 2009.-333c. 